\title{
IdeAs
}

Idées d'Amériques

$17 \mid 2021$

Villes et culture dans les Amériques

\section{Studying the Americas in the United Kingdom: a Preliminary Enquiry}

Jonathan Madison, Eduardo Posada-Carbó and Adam Smith

\section{OpenEdition}

Journals

Electronic version

URL: https://journals.openedition.org/ideas/10591

DOI: 10.4000/ideas.10591

ISSN: 1950-5701

Publisher

Institut des Amériques

\section{Electronic reference}

Jonathan Madison, Eduardo Posada-Carbó and Adam Smith, "Studying the Americas in the United Kingdom: a Preliminary Enquiry", IdeAs [Online], 17 | 2021, Online since 01 March 2021, connection on 03 June 2021. URL: http://journals.openedition.org/ideas/10591 ; DOI: https://doi.org/10.4000/ideas 10591

This text was automatically generated on 3 June 2021.

\section{$\Theta \Theta \Theta$}

IdeAs - Idées d'Amériques est mis à disposition selon les termes de la licence Creative Commons Attribution - Pas d'Utilisation Commerciale - Pas de Modification 4.0 International. 


\title{
Studying the Americas in the United Kingdom: a Preliminary Enquiry
}

\author{
Jonathan Madison, Eduardo Posada-Carbó and Adam Smith
}

\section{I}

1 "American studies" in the United Kingdom have a long tradition. The name itself is misleading, however, since in the U.K. it has usually refereed to the study of the United States. With a few exceptions Canada tends to be left out: together with other former British possessions in the Caribbean and the mainland, it had been integrated into studies of the Commonwealth, though Canadian Studies also took a path of its own since the $1970 \mathrm{~s}^{1}$. Latin American Studies in turn have encompassed the continent south of the Rio Grande but excluding the Caribbean islands (except Cuba and the Dominican Republic) and other former non-Spanish European colonies. Studying the Americas as a whole is therefore a relatively new area in U.K. universities, though there have been valuable attempts by individual scholars and institutions in the past. In this paper, we focus our attention on some recent initiatives trying to map the current "state of affairs" and identify a possible agenda to further our knowledge of the Americas as a field for comparative studies.

\section{II}

2 While we will not be dealing with the separate efforts to develop the studies of the various components of the Americas, it is worth noting some of the important antecedents. A few individual scholars, such as James Bryce, attempted to understand "the two Americas" and ventured comparative exercises ${ }^{2}$. However, as an academic field, the development of "American [U.S.] studies" took place from the 1950s, following the foundation of the British Association of American Studies, though some university chairs had been established in previous decades such as the Harmsworth professorship (Oxford, 1922), the Commonwealth Chair in American History (London,1930), the Pitt 
professorship (Cambridge,1944). "Oxford and Cambridge have begun to study the United States", observed Edgar W. Wesley in 1962, though the U.S. remained very marginal to the curriculum. Explaining the "delays and frustrations in inaugurating American Studies" in the U.K., he noted "that insular completeness [...], that blindness to other countries and cultures that do not endear the British to Latin Americans, nor to their cousins [...] in the United States" ${ }^{3}$. The earliest scholars of the U.S. were often historians of Britain who were extending their interests, often with the inducement of well-paid sabbaticals to the United States paid for, either directly or indirectly, by the U.S. State Department, whose "soft power" investment in U.S. studies had a big impact on the early development of the discipline in the U.K.

3 Latin American Studies also developed during the second half of the $20^{\text {th }}$ century. University College London (UCL) had established a chair in the history of the region in 1948, but the field "officially" took-off in the 1960s, particularly after five Latin American Centres were set up in Liverpool, Glasgow, Oxford, Cambridge and London, on the recommendation of the sub-committee of the University Grants Committee in $1965^{4}$. Yet by the time the report was published there were at least nine posts in U.K. universities, also including Manchester, Edinburgh and Bristol - indeed a "group of university lecturers with an interest in Latin American affairs" had been formed in 1962, leading to the establishment of the Society of Latin American Studies two years later ${ }^{5}$. Thus both U.S. and Latin American studies came of an age almost simultaneously.

4 Since their inception the "American Studies" (i.e. U.S. studies) and Latin American programmes spread throughout the university system, each pursuing their own path ${ }^{6}$. There were, however, some attempts to bring the various strands of the study of the Americas under one roof. That was the case of the School of Comparative American Studies (CAS) established at Warwick in 1974, the "brainchild" of Alistair Hennessy who advocated "comparing where possible the histories and cultures of Latin America, the United States, Canada and the Caribbean" 7 . It constituted a landmark in the field, as did the launch, three decades later, of the Institute for the Study of the Americas (ISA) at the University of London (the merger of the Institutes of U.S. and Latin American studies set up in the 1960s), which started to offer a master"s course on Comparative American Studies from 2005, under the leadership of James Dunkerley, whose own intellectual interests spanned the hemisphere ${ }^{8}$. Unfortunately, the "History, Literature and Cultures of the Americas" degree, hosted by CAS at Warwick, was discontinued in 2015. The ISA in London came to an end in 2012, though it was almost immediately reborn at UCL as the Institute for the Americas (more on this later), at a moment when the University of London was gradually ceasing to exist as a functioning federal institution and the largest constituent colleges, like UCL, applied for, and received, their own degree-awarding powers.

\section{III}

5 Very few have followed in the footsteps of the pioneers. Only a handful of institutions engaged in the study of the Americas as a cohesive unit, and, even within these exceptions, individual modules and academics still primarily focus on one of the subunits of analysis (U.S. or Latin America). Some do not offer specific degrees but fill an auxiliary role to aid students and researchers. The Centre for the Comparative Study of 
Portugal, Spain, and the Americas, at Swansea University, is one such institution though its primary focus is on the Luso-Hispanic world 9. Queen's University Belfast's Centre for the Americas hosts events for researchers of the hemisphere with the expressed aim of creating an integrated research culture. The Centre for the Americas at the University of York (YCA) provides support for the comparative study of the Americas by way of its Department of History, emphasizing the study both of the Americas comparatively across sub-regions and against other large regions. The Americas Research Cluster at the London School of Economics (LSE) brings together academics and researchers for a comparative study of political topics that incorporate the U.S., the Caribbean, and Latin America. There are, however, a few degree programmes that provide students with the opportunity to study the Americas as a whole. While American Studies at the University of East Anglia concern the United States alone, the university also offers a Master's Degree in the arts of Africa, Oceania, and the Americas. This degree includes a module that studies varying New World indigenous art traditions. The Centre for American Studies at the University of Kent offers both PhD and MA degrees but, while the centre appeals to students who wish to study the U.S. and Latin America, the vast majority of courses and opportunities revolve around the U.S.

The most comprehensive programme for the study of the Americas in the U.K. is that of UCL, mentioned above. It offers MA (taught Master's) programmes in U.S. studies, Latin American studies, and the comparative study of the Americas, and it launched an undergraduate degree in 2019 (the latter motivated by the funding structure of U.K. universities, where the recruitment of undergraduate students is often a condition for survival). The intellectual emphasis is on social science (especially economics and anthropology) and history rather than (as is typical at other U.K. American studies programmes) on literature. Several academic members of staff have interests that span Latin America and the U.S., though in practice the vast majority of students specialise in one or the other. Outside UCL, the most comprehensive degree programme in the U.K. is probably that of the University of Nottingham. Their American Studies and Latin American Studies BA Degree places students in a series of modules that encompass history, language, and culture across the hemisphere. Examples of these modules include Spanish language courses, U.S. foreign policy, and Canadian film and literature. In exceptional circumstances, students may study Brazil and Portuguese. All students spend a year abroad in either Spain or Spanish America; though, again students who qualify may spend this year in Portugal or Brazil.

7 Beyond the existence of institutions and programmes, there are other initiatives, either driven by informal networks of scholars or the work of individuals themselves. Consider some of the experiences in Oxford, to which the authors of this essay belong. In 1991, on the occasion of his inaugural lecture as Regius Professor, John Elliott warned his audience against "the dangers of historical provincialism" as he launched an agenda for comparative history, offering "America" as a relevant example worthy of exploration, though he placed it within the wider framework of the Atlantic ${ }^{10}$. Elliot made the case for comparative studies of colonial societies in the Americas, which he extended to the post-independent era. He himself went on to encourage the field by conducting seminars on the topic and by publishing his masterful account of the British and Spanish empires in the New World ${ }^{11}$. The study of the Americas in Oxford, however, has remained mostly structured around separate units: the Latin American 
Centre, established in the 1960s, and the Rothermere American Institute, in 2001. Yet this has not precluded collaboration. In 2012, both joined efforts in the organization of a conference on "Contentious Elections in the Americas, 1800-1910", which developed into a wider project to include the U.S., Canada, and Latin America. Both launched a joint seminar on the Comparative History of the Americas in 2014 which since then has hosted over 20 events.

Other initiatives have been established with a thematic focus. That is the case of the Radical Americas Network, set up in 2012, with the aim of highlighting "the benefits of hemispheric, comparative and transnational approaches to the study of the various historical, political and social contexts in which radicalism has developed in the Americas". The network has organised yearly symposiums and published a peer reviewed, open access journal, Radical Americas. In addition to these efforts, there are editorial houses which have book series dedicated to the history of the Americas, such as Routledge. Though most of its titles are on a national level, some of its publications include perspectives that cross the boundaries of the traditional sub-regions.

\section{IV}

9 "With these three things", James Bryce concluded back in 1913 in his brief comparative examination of the Americas after independence, "- republican forms, social equality, and detatchment from European politics, - the list of the things which the two Americas have in common ends" ${ }^{12}$. He had acknowledged a few "remarkable points of similarity" in earlier periods. But for him the resemblances were overshadowed by differences. Yet, as John Elliott argued in 1991, the value of comparative history "ultimately lies not so much in discovering the similarities as in identifying the differences" 13 . The differences between "Anglo" America and Latin America, especially the language divide, have profoundly structured the British study of the Americas both institutionally and intellectually. As the differences (above all in wealth and world power) grew between North and South America during the $20^{\text {th }}$ century, the reluctance of British scholars to compare them grew stronger, anchored in the notion of "exceptionalism" that has long permeated U.S. studies ${ }^{14}$. Even so, as Elliott also reminded us, there were some "areas of the study of the Americas", in particular the history of slavery, which were often analysed in hemispheric terms ${ }^{15}$. Elliott urged colleagues to turn to other subjects that were crying out for comparative study such as the frontier, immigration, settlement, government, and independence.

Much has happened since Bryce's observations, from the gradual consolidation of university centres set up to study its components to the various attempts to bring the study of the Americas together. As this essay has shown, since the 1950s a strong institutional set up developed in the U.K. to encourage the study of Latin America and the U.S., though each very much followed separate trajectories. However, from the 1970s, some prioneering efforts opened the way for the development of Comparative American Studies. This is not terra incognita, but it is still a territory full of unexplored, promising places. 


\section{NOTES}

1. Alan Hallsworth and Susan Hodgett, "Down but Not Out: British Academics Resolutely Determined to Explore Canada", in Stephen Brooks, Promoting Canadian Studies Abroad. Soft Power and Cultural Diplomacy (Palgrave Macmillan, 2019), 73-95. The British Association for Canadian Studies was established in 1975; idem, 76

2. Bryce first published his classic The American Commonwealth in 1888. His South America. Observations and Impressions (New York, 1913), the result of a four months trip in 1910, where he devoted a chapter to "the two Americas", is generally ignored.

3. Edgar B. Wesley, "American Studies in British Universities", Comparative Education Review, 5:3 (1962), 186-7. "No one library in Britain, university of public, has a first collection of Americana": this was the opening sentence of a "Bibliography of American Studies", published in the Bulletin of the British Association for American Studies, 1 (April 1956), 7.

4. See Gabriel Paquette, "The 'Parry Report' (1965) and the Establishment of Latin American Studies in the United Kingdom", The Historical Journal, 62:1 (2019), 219-40; Rory Miller, "Academic Entrepreneurs, Public Policy, and the Growth of Latin American Studies in Britain During the Cold War", Latin American Perspectives, 45: 4 (2018), 46-68; Harold Blakemore, "Latin American Studies in British Universities: Progress and Prospects", Bulletin of Latin American Research, 5:3 (1970), 111-34.

5. San Román, "The Rise of Modern Latin American Literary Studies in the U.K.: A Questionnaire to Early Practicioners", Bulletin of Spanish Studies, LXXXIV: 4-5 (2007), 452.

6. The expansion of both fields since then has been huge, as testified in several reports, but see "American Studies in the U.K., 2000-2010", in https://www.baas.ac.uk/wp-content/uploads/ 2010/03/american\%20studies\%20in\%20the\%20uk\%202000-2010.pdf; and Antoni Kapcia and Linda A Newson, Report on the State of UK-based Research on Latin America and the Caribbean (London, 2014).

7. McFarlane's testimony in "In Memoriam: Professor Alistair Hennessy", in https:// warwick.ac.uk/fac/arts/history/news/hennessy/ Among other works, Hennessy authored The Frontier in Latin American History (1978), where he engaged comparatively with theories of the frontier in the US. Other fellows from Warwick also published works in the field: for example, Guy Thomson on the impact of the 1848 European revolutions in the Americas and Tony McFarlane on the colonial and independence periods.

8. Dunkerley, Dreaming of Freedom in the Americas: Four Minds and a Name (London, 2004), 4. See Dunkerley, Americana. The Americas in the World Around 1850 (London, 2000).

9. For the information on the various programmes presented here we consulted their respective websites.

10. National and Comparative History. An Inaugural Lecture delivered before the University of Oxford on 10 May 1991 by John Elliott (Oxford, 1991), 15, 26-7.

11. Elliott, Empires of the Atlantic World. Britain and Spain in America, 1492-1830 (New Haven, 2016).

12. Bryce, South America, 504.

13. National and Comparative History, 24. See also Elliott's observations in his, History in the Making (New Haven, 2012), chapter 6.

14. Dunkerley, Dreams of Freedom, 5 .

15. Elliott, Do the Americas Have a Common History? An Address (Providence, 1996). 


\section{AUTHORS}

\section{JONATHAN MADISON}

Jonathan Madison is doctoral candidate in Global and Imperial History at the University of Oxford. His specialization is the history of democracy with regional focuses of Brazil and the United States of America. His thesis deals with democracy and democratization in 20 th century Brazil. He also produces journalistic pieces on Brazilian and U.S. politics. Example piece:

Madison, Jonathan Hembrough. "Brazil's Problem Is More than Just Jair Bolsonaro.” The Brazilian Report, May 31, 2020, sec. Opinion.

https://brazilian.report/opinion/2020/05/31/brazil-problem-is-more-than-just-jair-bolsonaro/.

\section{EDUARDO POSADA-CARBÓ}

Eduardo Posada-Carbó is Professor of the History and Politics of Latin America at Oxford University, where he is also William Golding Senior Research Fellow at Brasenose College. His works focuses on the history of democracy and elections on $19^{\text {th }}$ century Latin America. He is coediting (with Andrew Robertson) The Oxford Handbook of Revolutionary Elections in the Americas, 1800-1910 (forthcoming 2021) and (with Joanna Innes and Mark Philp), Re-Imagining Democracy in Latin America and the Caribbean, 1770-1870. He is currently the Director of the Latin American Centre in Oxford.

\section{ADAM SMITH}

Adam Smith is the Edward Orsborn Professor of United States Politics and Political History at the University of Oxford, the Director of the Rothermere American Institute and a Professorial Fellow of University College Oxford. He is a specialist in nineteenth-century U.S. politics. 